2. To: (Receiving Organization)

Fluor Daniel Hanford, Inc.

\section{Proj./Prog./Dept./Div.:}

Plutonium Finishing Plant

\section{Originator Remarks:}

This document is being distributed for functional review and approval.

11. Receiver Remarks:

11A. Design Baseline Document? $\bigcirc$ Yes

(C)
3. From: (Originating Organization)

$B \& W$ Hanford Company

6. Design Authority/Design Agent/Cog. Engr.:

A. I. Ramble

\section{Related EDT No.: \\ $\mathrm{N} / \mathrm{A}$ \\ 7. Purchase Order No.: \\ $N / A$ \\ 9. Equip./Component No.: \\ $\mathrm{N} / \mathrm{A}$ \\ 10. System/BIdg./Facility: \\ 2736-ZB \\ 12. Major Assm. Dwg. No: \\ $\mathrm{N} / \mathrm{A}$ \\ 13. Permit/Permit Application No: \\ $N / A$}

14. Required Response Date:

$\mathrm{N} / \mathrm{A}$

\begin{tabular}{|c|c|c|c|c|c|c|c|c|}
\hline 15. & & DATA TR & NSMITT & & $(F)$ & (G) & $(\mathrm{H})$ & (l) \\
\hline $\begin{array}{l}\text { (A) } \\
\text { Item } \\
\text { No. }\end{array}$ & (B) Document/Drawing No. & $\begin{array}{c}\text { (C) Sheet } \\
\text { No. }\end{array}$ & $\begin{array}{c}\text { (D) Rev. } \\
\text { No. }\end{array}$ & (E) Title or Description of Data Transmitted & $\begin{array}{l}\text { Approval } \\
\text { Desig- } \\
\text { nator }\end{array}$ & $\begin{array}{c}\text { Reason } \\
\text { for Trans- } \\
\text { mittal }\end{array}$ & $\begin{array}{c}\text { Origi- } \\
\text { nator } \\
\text { Dispo- } \\
\text { stion }\end{array}$ & $\begin{array}{c}\text { Receiv- } \\
\text { er } \\
\text { Dispo- } \\
\text { sition }\end{array}$ \\
\hline 1 & $\mathrm{HNE}-4823$ & - & 0 & Hazards Evaluation of & SQ & 1 & 1 & \\
\hline & & & & Plutonium Metal Opening & & & & \\
\hline & & & & and Stabilization & & & & \\
\hline & & & & & & & & \\
\hline & & & & & & & & \\
\hline & & & & & & & & \\
\hline & & & & & & & & \\
\hline
\end{tabular}

16.

KEY

\begin{tabular}{|c|c|c|c|c|}
\hline Approval Designator (F) & \multicolumn{2}{|c|}{ Reason for Transmittal (G) } & \multicolumn{2}{|c|}{ Disposition $(H) \&(1)$} \\
\hline $\begin{array}{l}E, S, Q, D O R \text { N/A } \\
\text { (See WHC-CM-3-5, } \\
\text { Sec. 12.7) }\end{array}$ & $\begin{array}{l}\text { 1. Approval } \\
\text { 2. Release } \\
\text { 3. Information }\end{array}$ & $\begin{array}{l}\text { 4. Review } \\
\text { 5. Post-Review } \\
\text { 6. Dist. (Receipt Acknow. Required) }\end{array}$ & $\begin{array}{l}\text { 1. Approved } \\
\text { 2. Approved w/comment } \\
\text { 3. Disapproved w/comment }\end{array}$ & $\begin{array}{l}\text { 4. Reviewed no/comment } \\
\text { 5. Reviewed w/comment } \\
6 \text {. Receipt acknowledged }\end{array}$ \\
\hline
\end{tabular}

17.

SIGNATURE/DISTRIBUTION

(See Approval Designator for required signatures)

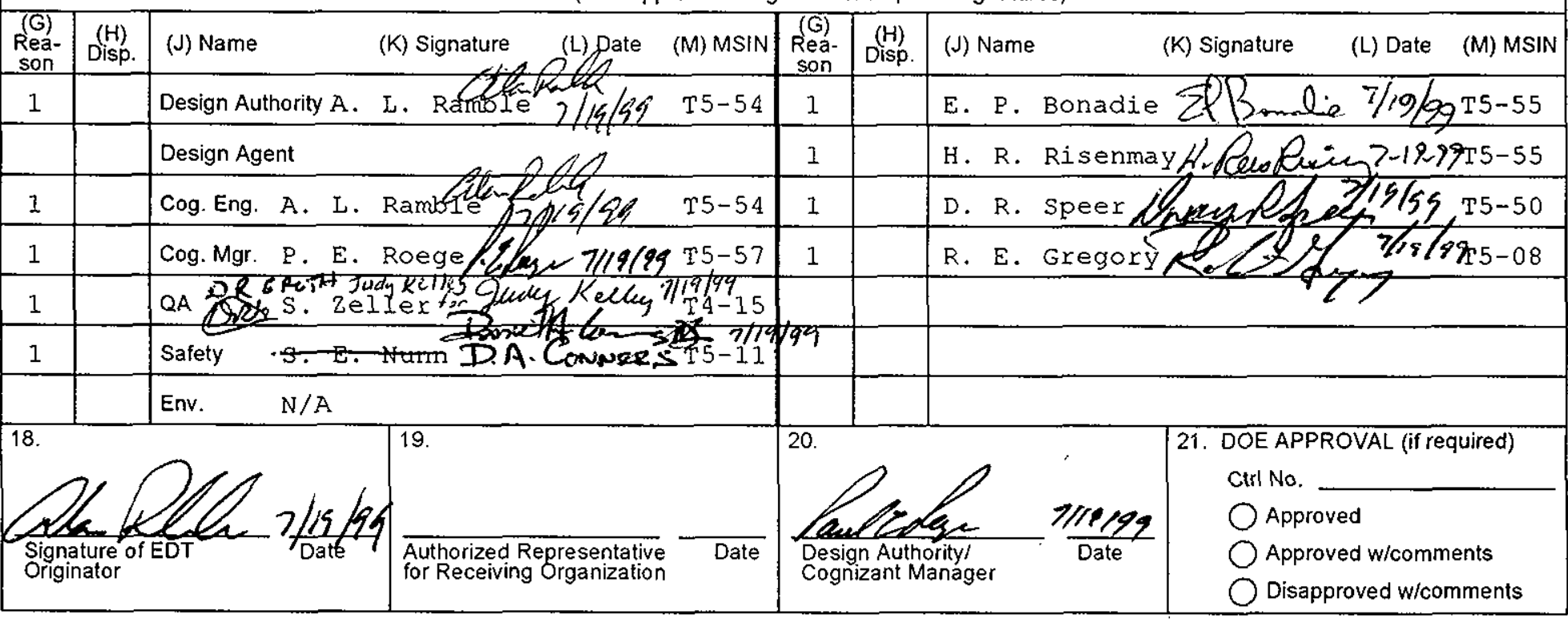


$\oint$

\title{
Hazards Evaluation of Plutonium Metal Opening and Stabilization
}

I. E. Johnson

Fluor Daniel Northwest, Inc.

Richland, WA 99352

U.S. Department of Energy Contract DE-AC06-96RL13200

\author{
EDT/ECN: 619986 UC: \\ Org Code: 403 \\ B\&R Code: EW7002010 \\ Charge Code: $101418 \mathrm{BB} 20$ \\ Total Pages: 25
}

Key Words: Pu metal, corrosion products, sampling, testing, packaging

Abstract: Hazards evaluation is the analysis of the significance of hazardous situations associated with an activity or process. The HE used qualitative techniques of Hazard and Operability (HazOp) analysis and What-If analysis to identify those elements of handling and thermal stabilization processing that could lead to accidents.

TRADEMARK DISCLAIMER. Reference herein to any specific commercial product, process, or service by trade name, trademark, manufacturer, or otherwise, does not necessarily constitute or imply its endorsement, recommendation, or favoring by the United States Government or any agency thereof or its contractors or subcontractors.

Printed in the United States of America. To obtain copies of this document, contact: Document Control Services, P.O. Box 950, Mailstop H6-08, Richland WA 99352, Phone (509) 372-2420; Fax (509) 376-4989.

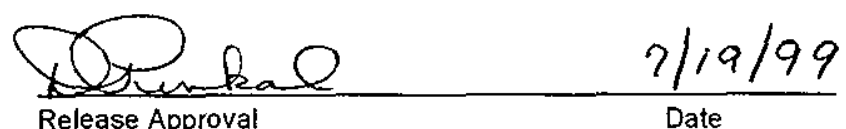

Release Approval

Date

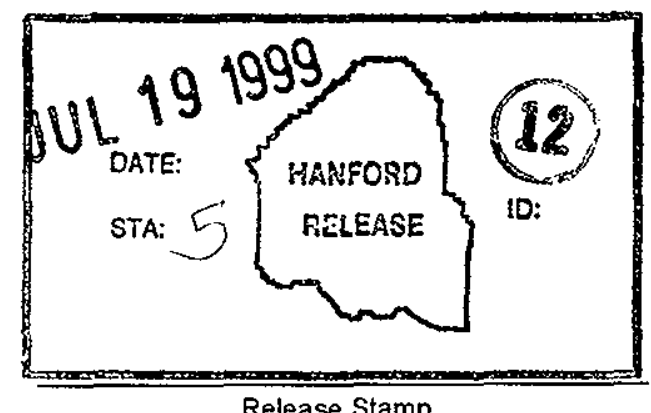

Approved For Public Release 


\section{HAZARDS EVALUATION OF PLUTONIUM METAL OPENING AND STABILIZATION}

Prepared by:

Fluor Daniel Northwest, Inc.

For:

B\&W Hanford, Inc.

Date Published

July 1999

Approved by:

B\&W Hanford, Inc.

July 1999

Prepared for the U. S. Department of Energy

FLUOR DANIEL
HANFORD, INC. Richland, Washington

Hanford Management and Integration Contractor for the

U.S. Department of Energy under Contract DE-AC06-96RL13200 
HNF-4823 Rev. 0

This page intentionally left blank. 


\section{TABLE OF CONTENTS}

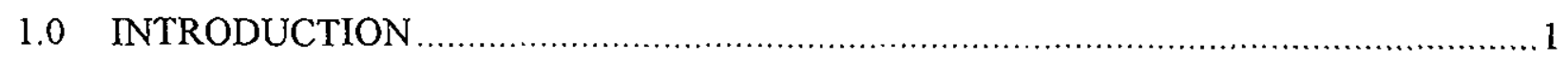

2.0 METAL OPENING AND STABILIZATION ACTIVITY ANALYZED ...................... 1

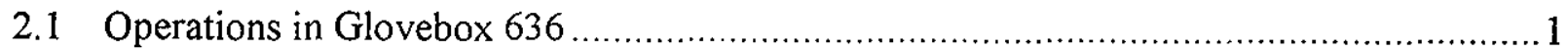

2.2 Subsequent Stabilization Operations in Gloveboxes HC-21 A, HC-21C, and HC-18M.... 2

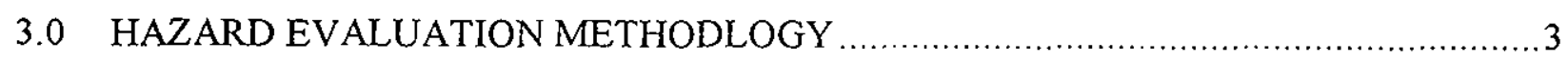

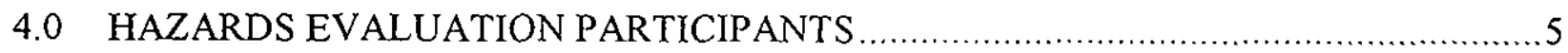

5.0 HAZARDS EVALUATION WORKSHEET ORGANIZATION $\ldots \ldots \ldots \ldots \ldots \ldots \ldots \ldots \ldots \ldots . . . \ldots$

6.0 HAZARD EVALUATION RESULTS ........................................................ 19 
HNF-4823 Rev. 0

This page intentionally left blank. 


\section{HAZARDS EVALUATION OF PLUTONIUM METAL OPENING AND STABILIZATION}

\subsection{INTRODUCTION}

A Hazards Evaluation (HE) was done for the opening of containers of Pu metal, conversion of the metal and corrosion products to plutonium oxide product, and sampling, testing and packaging the product. Hazards evaluation is the analysis of the significance of hazardous situations associated with an activity or process. The HE used the qualitative techniques of Hazard and Operability (HazOp) analysis and What-If analysis to identify those elements of handling and thermal stabilization processing that could lead to accidents.

\subsection{METAL OPENING AND STABILIZATION ACTIVITY ANALYZED}

\subsection{OPERATIONS IN GLOVEBOX 636}

The following is a sequential listing of the metal opening operations that will normally be done in the 636 Glovebox. These steps were identified during the HE team meetings and are the substance of the activity rather than the final procedural form and format. These are the steps that are identified in the HE worksheets with an "OM" identifier in the "Node ID" column.

1. Segregate, remove or minimize all combustibles to far end of glovebox.

2. Inspect outermost can to determine if it's a suspect (bulged, paneled, weight gained) can.

3. If suspect, punch can and wait until no further obvious reactions ongoing.

4. Open can with can opener.

5. If lid falls in can, remove lid from can with dulled screwdriver or tweezers.

6. Inspect material within can.

7. If contents are another can, go to step 2.

8. If contents are burning product, place slip-lid on top of product can. (may curtail operations until burning stops) -Seal it into a slip-lid can, bag it out, can it, and transfer it directly to Glovebox HC-21A to be thermally stabilized.

9. If contents appear to be normal product, pour contents into open container (tray, boat, can). 
10. Separate corrosion products from metal:
a. brush whole, stable button with bristle brush
b. move clean stable button to a new can.

11. If contents are not a whole, stable button (per STA/Operator decision); re-can for transfer to Glovebox HC-21A.

12. When a maximum of $200 \mathrm{~g}$ of brushings have accumulated, can and transfer to Glovebox HC-21 A.

Note: differences in operation in this GB636 \& Glovebox HC-21A - 636 handles it more, no canning in Glovebox HC-21 A, when opened in Glovebox HC-21 A, it's poured into a boat, then conveyed to Glovebox $\mathrm{HC}-21 \mathrm{C} \&$ thermally stabilized, and conveyed to and finally canned in GB $18 \mathrm{M}$.

\subsection{SUBSEQUENT STABILIZATION OPERATIONS IN GLOVEBOXES HC-21A, HC-21C, AND HC-18M}

The following is a sequential listing of the metal opening operations that will normally be done in the Glovebox HC-21A. These steps were identified during the $\mathrm{HE}$ team meetings and are the substance of the activity rather than the final procedural form and format. These are the steps that are identified in the HE worksheets with an "TS" identifier in the "Node ID" column.

1. Seal-in Pu container into Glovebox $\mathrm{HC}-21 \mathrm{~A}$, weigh Pu container, and furnace boat for Pu material accountability purposes.

2. Punch suspect (bulged or paneled) outer containers to relieve pressure or vacuum (typically performed in GB636).

3. Open Pu containers (includes punching and opening, if necessary, of overpack containers and inner container of $\mathrm{Pu}$ metal).

4. Remove materials (maybe corrosion products, metal or any combination of both) from containers and place in furnace boat.

5. Transfer furnace boat with boatcover to HC-2. Bag-out empty cans, plastic bags and tape as needed.

6. Transfer furnace boat with cover from Glovebox HC-21A to Glovebox HC-21C via conveyor or passed by hand via conveyor glovebox.

7. Remove the boatcover from the furnace boat, place boat in the furnace and operate the furnace. 
8. At the end of the cool down cycle, open furnace and remove boat. After further cooling, inspect for degree of stabilization and reprocess as necessary.

9. Upon completion of stabilization and cool down, transfer furnace boat to $\mathrm{HC}-18 \mathrm{M}$ via HC-2 for sieve/grinding, place in can and sample.

10. Transfer can to Glovebox HC-18BS for interim storage pending sampling results.

11. If the sample passes LOI, transfer to HC-18M, bag-out and can. If the sample does not pass LOI, return material to Glovebox HC-21A for reprocessing.

In addition to the above operations, the relevant utilities associated with the plutonium metal stabilization process were examined. The specific utilities evaluated were the glovebox fire suppression system, the E-4 ventilation system that exhausts the gloveboxes, the power supply to the RMC Line equipment, and the 26-inch- $\mathrm{Hg}$ vacuum system that exhausts the muffle furnaces in Glovebox $\mathrm{HC}-21 \mathrm{C}$.

\subsection{HAZARD EVALUATION METHODLOGY}

The HE process is one that employs a systematic approach in the identification of hazards associated with a system, or process. The process is one in which the system or process is broken down into its basic elements and the hazards associated with each element are identified. Potential causes of those hazards are determined, potential consequences estimated and evaluated and possible corrective and/or preventative measures are considered. The HE was developed using a table to guide and record the results of a What-If brainstorming process. The What-If technique was combined with Hazard and Operability analysis system of using guidewords in conjunction with process parameters or procedure activities to arrive at an unintended deviation. By this method, structure was given to the otherwise unstructured What-If analysis technique. This guided What-If brainstorming was performed by individuals with detailed knowledge of the system or processes being examined, and was supported by a multi-disciplinary team familiar with the operation. A detailed discussion of the HE techniques of HazOp analysis and What-If analysis can be found in Guidelines for Hazard Evaluation Procedures (AIChE 1992).

The purpose and contents of each column in the HE sample table, Table B-1, are described in detail in the following paragraphs.

Column 1, Node ID: This column provides an alpha-numeric identifier for each hazard postulated in the table. The identifier is primarily used for cross-referencing within the table and as an identifier for accident sequences.

Column 2, Step \#: The step or steps involved in performing each set of operations is identified in this column. 
Column 3, "What-If" question: The deviation from the intended action put in the form of a "what if" question. The questions being generated using a set of deviation guide words. The deviation guides are the same as those used in a HazOp analysis.

Column 4, Consequence: Both the immediate and ultimate consequence of the activity/operational "What-If" deviation that could result are recorded in this column.

Column 5, Causes: This column identifies the causes for both the What-If and the ultimate accident sequence conclusion.

Column 6, Engineered Safety Feature(s) for "What-1f" and Accident: This column identifies the engineered features (hardware items) intended or available to prevent or mitigate the consequences identified in Column 4.

Column 7, Administrative Safety Feature(s) for "What-If" and Accident: This column identifies the administrative requirements that reduce the likelihood of both the What-If event (if applicable) and the Accident event consequences identified in Column 4, or that help minimize the potential consequences of the Accident event.

Column 8, Consequence Category: This column is used to capture a code designator for the level of consequence associated with a hazardous event. The consequence ranking is the initial, qualitative estimate of the safety severity of the consequences. An alpha-numeric system has been used at the PFP to designate the severity of hazardous events. The system has the following "S" rankings characterizing safety consequences:

So No effect outside the glovebox confinement systems; negligible safety concerns for the facility worker.

S1 Potential industrial injury, low radiological or chemical exposure dose consequences to the facility worker.

$\mathrm{S} 1$ * Potential severe harm or potential death from industrial injury, radiological dose or chemical exposure to the facility worker.

S2 Potential significant radiological dose consequences or chemical exposure to onsite workers located outside the facility.

S3 Potential significant radiological dose consequences or chemical exposure to the offsite population.

Column 9, Frequency Ranking: This column shows the estimated frequency of occurrence. The frequency ranking is a first cut, qualitative estimate of the likelihood of the hazardous event. The following ranking system is used. 
F3 Events that are expected to occur one or more times during the lifetime of the facility, categorized as "anticipated" events. The frequency range associated with this category is $1 \mathrm{E}-02 / \mathrm{yr}$ to $0.1 / \mathrm{yr}$.

F2 Events that could occur during the lifetime of the facility, but with low probability. Such events are categorized as "unlikely" and fall in the range of $1 \mathrm{E}-$ $04 / \mathrm{yr}$ to $1 \mathrm{E}-02 / \mathrm{yr}$.

F1 Events not expected to occur during the lifetime of the facility categorized as "extremely unlikely." The frequency range associated with this category is 1E06/yr to $1 \mathrm{E}-04 / \mathrm{yr}$.

F0 Events categorized as "beyond extremely unlikely," with a frequency less than 1E-06/yr. Events in this category (such as meteor strike) are so unlikely they generally do not require special controls.

The frequency estimate, like the consequence ranking, is assigned taking no credit for active engineered features.

Column 10, Remarks: This column contains miscellaneous observations or clarifying comments for a given hazard.

\subsection{HAZARDS EVALUATION PARTICIPANTS}

This section contains the professional biographies of the participants of the PHA.

\section{David M. Carson - Fluor Daniel Northwest - Specialty Engineer}

Mr. Carson is currently employed in the SAR Engineering Services section of the Specialty Engineering group of Fluor Daniel Northwest. He has eight years of Nuclear Reactor Operator experience, having been a certified Operator at $\mathrm{N}$ Reactor, followed by nine years of Technical, Procedure, and Manual writing and editing experience from Tank Farms, Effluent Treatment, the Spent Nuclear Fuel Project, and Specialty Engineering. Mr. Carson has been trained in Process Hazard Analysis techniques, and has participated in development of the HazOp process as used in Specialty Engineering.

\section{Craig Carro - M.H. Chew \& Associates, Inc., Safety Analyst}

Mr. Carro has a total of 17 years experience as a safety professional supporting DOE activities at the Rocky Flats site, Lawrence Livermore National Laboratory, and the Hanford site. For 13 years he has prepared authorization basis documents for facilities at the Hanford site including the PFP, Central Waste Complex, TRUSAF, TWRS, 242-A Evaporator and several others. Mr. Carro has a Bachelor of Science Degree in Fisheries with an aquatic ecology emphasis from the University of Washington, and a Masters Degree in Radiological Sciences with a radiation 
biology emphasis from the School of Public Health and Community Medicine at the University of Washington.

Robert M. Marusich - Fluor Daniel Northwest, Inc., Engineer, Safety Analysis and Risk Assessment

Mr. Marusich has over 28 years experience in safety analysis. Mr. Marusich's experience includes both commercial reactors and DOE nuclear and non-nuclear facilities. He was also contributor and later Manager of the Probabilistic Risk Assessment (PRA) Group at Consumers Power Co. in charge of the Palisades and Big Rock Point PRA's. Mr. Marusich's area of expertise is consequence analysis. He has performed consequence analysis many of the processes performed within each of the Hanford facilities. Mr. Marusich has been performing consequence analyses for PFP for 11 years and has worked on numerous processes within PFP. Mr. Marusich has a B.S. and M.S. in Nuclear Engineering from the University of Wisconsin.

\section{Aurora B. Rau - Fluor Daniel Northwest - Specialty Engineer}

Mrs. Rau is currently employed in the SAR Engineering Services section of the Specialty Engineering group of Fluor Daniel Northwest. She has a total of 23 years of experience in the Hanford site documentation as well as a certified TRIGA reactor operator. She has eight years of experience in the documentation of Safety Analysis as well as Criticality Safety Evaluation Reports and other supporting documentation.

H. Rees Risenmay - B\&W Hanford Co., Engineer, PFP Process Engineering, Solids Stabilization Cognizant Engineer

Mr. Risenmay has 16 years experience at the Hanford site. His experience has been in the Chemical Engineering Laboratory, the PUREX plant, the U03 plant, and the PFP plant. His experience is mostly in process engineering with detailed knowledge of the processes and safety aspects for each plant. Mr. Risenmay has a Bachelor of Science Degree in Chemistry from Brigham Young University and a Bachelor of Science Degree in Engineering with chemical engineering emphasis from the University of Washington.

Errol Bonadie - B\&W Hanford Company - Cognizant Engineer - Packaging \& Shipping

Mr. Bonadie has worked at the Plutonium Finishing Plant since 1983. He is currently the Cognizant Engineer for Packaging and Shipping and he served as the Vault Cognizant Engineer from 1990 through 1997. Mr. Bonadie has a B.S. degree in Chemical Engineering from the Pratt Institute of New York. He also attended the New York University School of Education and the Howard University School of Engineering \& Architecture.

\section{Dennis A. Clapp - Fluor Daniel Northwest - Senior Specialty Engineer}

Mr. Clapp is currently employed in the Safety Analysis and Risk Assessment section of the Specialty Engineering group of Fluor Daniel Northwest. He has been at the Hanford Site for 23 years. He has experience in nuclear power plant construction as a construction contract 
administrator, field engineer, design engineer, and construction engineer. His Hanford Operations Contractor work experience includes conceptual design, Hanford Waste Vitrification Plant project design oversight, and safety analysis. His last 13 years have been in safety analysis. Mr. Clapp is certified by the Process Safety Institute as a Hazards Assessment Team Leader using the HazOp and What-If/Checklist techniques. His education is Bachelor of Science in Chemical Engineering from the University of New Mexico.

\section{Edward Wallace - Lead Nuclear Chemical Operator - Fluor Daniel Hanford Company}

Mr. Wallace has more than 16 year of experience at the Plutonium Finishing Plant. He has worked in Vault Operations for 10 years and has been a Lead Operator since 1989. Mr. Wallace is responsible for moving and/or supervising the movement of fissile material to and from process operations and storage arrays (including vaults) within the PFP complex.

\section{Edward Kauer - Lead Nuclear Chemical Operator - Fluor Daniel Hanford Company}

Mr. Kauer has more than 10 years of experience at the Plutonium Finishing Plant. He is currently working for the TSST team. He is certified in Thermal Stabilization operations, in Loadin/Loadout Plutonium nitrate operations and in General Plant operations. He has been a lead operator since 1990. He is responsible for moving and /or supervising the movement of fissile material to and from process operations and storage arrays within the PFP complex.

\section{Thurman Cooper - B\&W Hanford Company}

Mr. Cooper graduated from Oregon State University with an M.S. in chemistry in 1973. Concurrent with his education, he spent 8 years on the OSU staff as a radiochemist, followed by 3 years working for Morrison Knudsen Inc. as a health physics manager and 23 years as a plutonium development chemist at the Plutonium Finishing Plant. Mr. Cooper is a member of the senior science advisory panel (also called the Critical Mass Working Group). The function of this group is to review site projects and processes and provide scientific advice to senior plant management. Mr. Cooper's professional interests include plutonium chemistry, reaction kinetics, thermodynamics, hydride chemistry, and modeling of chemical reactions. Mr. Cooper's models have played a role in safety assessments of plant processes. Examples of these assessments include:

\footnotetext{
* Radiolytic gas generation from plutonium compounds during vault storage.

* Radiolytic gas generation from plutonium nitrate solutions.

* Safe handling of Pu corrosion products in air-filled gloveboxes.

* Dust emission potential from the vertical calciner during off-normal conditions.
} 
Robert B. Gelman - Process Engineer - Fluor Daniel Northwest, Inc.

Mr. Gelman received in BS in Chemical Engineering from Carnegie Mellon University, and his MBA from the University of Pittsburgh. He has 31 years of nuclear processing experience with the 23 of those at Hanford. He is the former facility manager for the Plutonium Finishing Plant, Hanford Waste Tank Processing Manager, Chemical Processing Quality Assurance Manager, 242-A Evaporator Restart Manager, TWRS Safety Basis Implementation Manager. He is regarded as an expert in nuclear facility management, conduct of operations, quality assurance, and program management. He is currently appointed to the ASME Nuclear Quality Assurance Subcommittee on Applications.

\subsection{HAZARDS EVALUATION WORKSHEET ORGANIZATION}

The HE table structure used in this analysis is provided in Table A-1. The HE table is structured to ensure a systematic and thorough review of potential hazards. The thermal stabilization of metal and metal corrosion products is broken down into logical sets of operations performed at specific locations. The operational steps covered in the analysis were identified from verbal descriptions provided by the cognizant engineers and other available information and were identified in section A.2. 
Table 1. Hazards Evaluation Worksheet Form

Deviation Guides: (1) No, None (2) Less, Lower (3) More, Higher (4) Part of (5) As Well As (6) Reverse (7) Other Than, Sooner, Later, Where Else

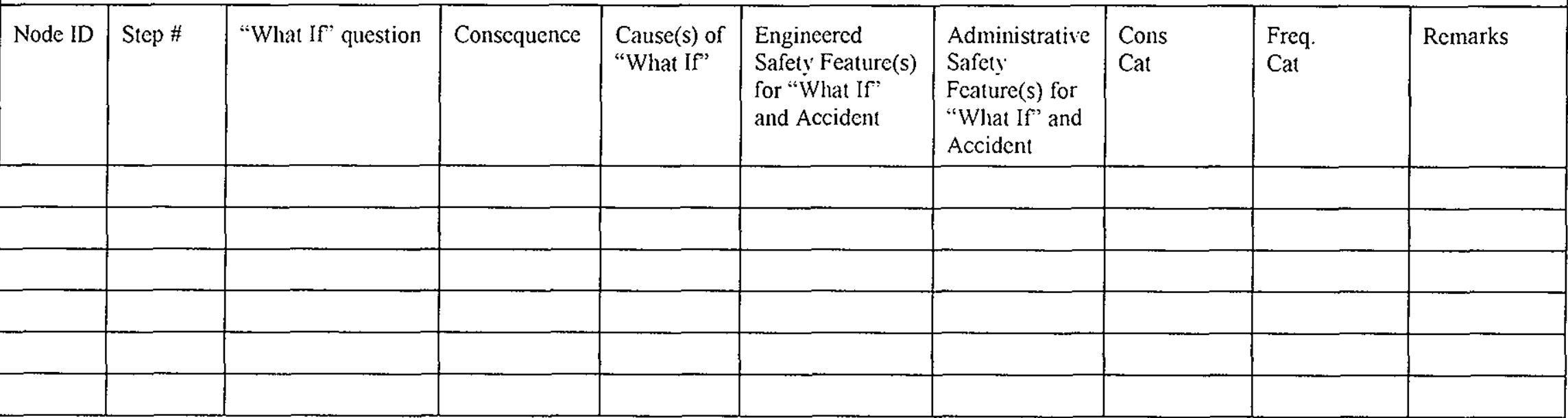


HNF-4823 Rev. 0

This page intentionally left blank. 
Table 2. Hazards Evaluation Worksheets

PFP Opening Metal Items in 636GB "What If" Hazards Evaluation Work Sheets

Hazards Evaluation Team: R.B. Gelman, E.P. Bonadie, T.D. Cooper, E.E. Wallace, E.L. Kauer, H.R. Risenmay, C.A. Carro, R.M. Marusich, D.A. Clapp, Leader, D.M. Carson Scribe Date Hazards Evaluation Conducted: 9 June 1999

\begin{tabular}{|c|c|c|c|c|c|c|c|c|c|}
\hline $\begin{array}{l}\text { Node } \\
\text { ID }\end{array}$ & Step \# & "What If" question & Consequence & Cause(s) of "What If" & $\begin{array}{l}\text { Engineered Safety } \\
\text { Feature(s) for "What If" } \\
\text { and Accident }\end{array}$ & $\begin{array}{l}\text { Administrative } \\
\text { Safety Feature(s) } \\
\text { for "What If" and } \\
\text { Accident }\end{array}$ & $\begin{array}{l}\text { Cons } \\
\text { Cat }\end{array}$ & $\begin{array}{l}\text { Freq } \\
\text { Cat }\end{array}$ & Remarks \\
\hline ONt-1a & 1 & $\begin{array}{l}\text { What if combustibles not segregated } \\
\text { or removed before operations begin? }\end{array}$ & $\begin{array}{l}\text { Increased severity of fire due to } \\
\text { higher combustible loading. } \\
\text { Accident: fire initiated by sparks } \\
\text { from opened can. }\end{array}$ & l'oor housckeeping. & $\begin{array}{l}\text { WI: None. } \\
\text { A: Bayonet-equipped fire } \\
\text { extinguishers: in-glovebox fire } \\
\text { extinguisler with quick-disconnec } \\
\text { (636); MgO sand; Halon (21.A): }\end{array}$ & $\begin{array}{l}\text { WI: Procedural comtrol: } \\
\text { training. } \\
\text { A: Training in use of fire } \\
\text { suppression equipment } \\
\text { and materials. }\end{array}$ & $\begin{array}{l}\text { WI: } \\
\text { S0 } \\
\text { A: } \\
\text { Sl }\end{array}$ & $\begin{array}{l}\text { W': } \\
\text { F3 } \\
\text { A: } \\
\text { F2 }\end{array}$ & $\begin{array}{l}\text { Credit taken for SC ventilation } \\
\text { HEPA filters. } \\
\text { Frequencies are given with } \\
\text { controls in place. }\end{array}$ \\
\hline OM-lb & 1 & $\begin{array}{l}\text { What if combustibles generated } \\
\text { during operations not segregated or } \\
\text { removed? }\end{array}$ & $\begin{array}{l}\text { Increased severity of fire diue to } \\
\text { higher combustible loading. } \\
\text { Accident: fire initialed by sparks } \\
\text { from opened cant. }\end{array}$ & Poor housckeeping. & $\begin{array}{l}\text { W': None. } \\
\text { A: Bayonet-equipped fire } \\
\text { extinguishers; in-glocebox fire } \\
\text { extinguisher with quick-disconnect } \\
\text { (636); MgO sand; Ilalon }(21 \mathrm{~A}) \text {;. }\end{array}$ & $\begin{array}{l}\text { WI: Procedural control; } \\
\text { training. } \\
\text { A: Training in use of firc } \\
\text { suppression equipment } \\
\text { and materials. }\end{array}$ & $\begin{array}{l}\text { WI: } \\
\text { So } \\
\text { A: } \\
\text { Si }\end{array}$ & $\begin{array}{l}\text { W'I: } \\
\text { F3 } \\
\text { A: } \\
\text { F2 }\end{array}$ & \\
\hline ON-le & 1 & $\begin{array}{l}\text { What if combustibles segregated but } \\
\text { never removed before operations } \\
\text { begin? }\end{array}$ & $\begin{array}{l}\text { Increased severity of fire duc to } \\
\text { ligher combustible loading. } \\
\text { Accident: fire initialed by sparks } \\
\text { from opened can. }\end{array}$ & Poor housekeeping. & $\begin{array}{l}\text { WI: None. } \\
\text { A: Bavonet-equipped fire } \\
\text { extinguishers; in-glovebox fire } \\
\text { extinguisher with quick-disconnec } \\
\text { (636); MgO sand; Halon (21A);. }\end{array}$ & $\begin{array}{l}\text { WI: Procedural control; } \\
\text { training. } \\
\text { A: Training in use of fire } \\
\text { suppression equipment } \\
\text { and materials. }\end{array}$ & $\begin{array}{l}\text { WI: } \\
\text { So } \\
\text { A: } \\
\text { S1 }\end{array}$ & $\begin{array}{l}\text { WI: } \\
\text { F2 } \\
\text { A: } \\
\text { F1 }\end{array}$ & \\
\hline OM-1d & 1 & $\begin{array}{l}\text { What if unused gloves are not pulled } \\
\text { out from glorebox before operations } \\
\text { begin? }\end{array}$ & $\begin{array}{l}\text { Breach of glove with subsequent } \\
\text { spread of contamination. } \\
\text { A: fire initiated by sparks from } \\
\text { opened can. }\end{array}$ & Human Error & $\begin{array}{l}\text { WI: none. } \\
\text { A: gloves are self-extinguishing: } \\
\text { Room CAMs; Halon system sends } \\
\text { fire Alarm (21A); room fire } \\
\text { suppression }\end{array}$ & $\begin{array}{l}\text { WI: Procedural control; } \\
\text { training. } \\
\text { A: Training in use of fire } \\
\text { suppression equipment } \\
\text { and materials. }\end{array}$ & $\begin{array}{l}\text { WI: } \\
\text { so } \\
\text { A: } \\
\text { S1 }\end{array}$ & $\begin{array}{l}\text { WI: } \\
\text { F3 } \\
\text { A: } \\
\text { F2 }\end{array}$ & $\begin{array}{l}\text { Check for } 636 \text { fire } \\
\text { detection/Alarms. }\end{array}$ \\
\hline
\end{tabular}




\begin{tabular}{|c|c|c|c|c|c|c|c|c|c|}
\hline \multicolumn{10}{|c|}{ Deviation Guides: (1) No, None (2) Less, Lower (3) More, Higher (4) Part of (5) As Well As (6) Reverse (7) Other Than, Sooner, Later, Where Else } \\
\hline $\begin{array}{l}\text { Node } \\
\text { ID }\end{array}$ & Step \# & "What If" question & Consequence & Cause(s) of "What If" & $\begin{array}{l}\text { Engineered Safety } \\
\text { Feature(s) for "What If" } \\
\text { and Accident }\end{array}$ & $\begin{array}{l}\text { Administrative } \\
\text { Safety Feature(s) } \\
\text { for "What If" and } \\
\text { Accident }\end{array}$ & $\begin{array}{l}\text { Cons } \\
\text { Cat }\end{array}$ & $\begin{array}{l}\text { Freq } \\
\text { Cat }\end{array}$ & Remarks \\
\hline $\mathrm{OM}-2$ & 2 & What if we did not inspect a can? & See Remarks & See Remarks & See Remarks & See Remarks & & & $\begin{array}{l}\text { Consequences determined by step } \\
3 \text {. }\end{array}$ \\
\hline OM-3a & 3 & $\begin{array}{l}\text { What if we just opened a bulged } \\
\text { suspect can without punching it first? }\end{array}$ & $\begin{array}{l}\text { Release of Hydrogen from can } \\
\text { A: Ignition of Hydrogen released } \\
\text { from can. }\end{array}$ & See Remarks & See Remarks & See Remarks & $\begin{array}{l}\text { WI: } \\
S \\
\text { A: } \\
S\end{array}$ & $\begin{array}{l}\text { WI: } \\
\text { F } \\
\text { A: } \\
\text { F }\end{array}$ & $\begin{array}{l}\text { Release and ignition of Hydrogen } \\
\text { from a can is covered in Thermal } \\
\text { Stabilization Addendum and in } \\
\text { Rev. } 1 \text { to the PFP FS.R. } \\
\text { Not a unique hazard to this } \\
\text { operation. }\end{array}$ \\
\hline $\mathrm{OAl}-3 \mathrm{~b}$ & 3 & $\begin{array}{l}\text { What if we just opened a pancled } \\
\text { suspect can without punching it first? }\end{array}$ & $\begin{array}{l}\text { Increased reaction rate of contents } \\
\text { (liydrides) } \\
\\
\text { A: "Sparky": (1) provides ignition } \\
\text { source for combustibles in } \\
\text { gloveboox; (2) pressurnization of } \\
\text { glorebox;, (3) provides increased } \\
\text { particulate into glovebox. }\end{array}$ & Human error. & $\begin{array}{l}\text { WI: none. } \\
\text { A: (1) same as fire } \\
\text { (2) ventilation system } \\
\text { (3) glovebox containmemt }\end{array}$ & $\begin{array}{l}\text { W'I: Procedure } \\
\text { compliance; training. } \\
\text { A: (1) same as fire } \\
\text { (2) none } \\
\text { (3) none }\end{array}$ & $\begin{array}{l}\text { WI: } \\
\text { So } \\
\text { A: } \\
\text { 1)SI } \\
\text { 2) SO } \\
\text { 3)SO }\end{array}$ & $\begin{array}{l}\text { WI: } \\
\mathrm{F} 3 \\
\text { A: } \\
\text { 1) } \mathrm{F} 3 \\
\text { 2)F3 } \\
\text { 3) } \mathrm{F} 3\end{array}$ & $\begin{array}{l}\text { Hydride bounds. } \\
\text { To cause a fire, combustibles must } \\
\text { be present. } \\
\text { Calculations show that } \\
\text { pressurization and particulate } \\
\text { wents are inconsequemial. }\end{array}$ \\
\hline ON-3c & 3 & $\begin{array}{l}\text { W'lat if we just opened a "weight- } \\
\text { gain" suspect can without punching it } \\
\text { first? }\end{array}$ & $\begin{array}{l}\text { Bounded by ON-3b. } \\
\text { A: }\end{array}$ & See Remarks & See Remarks & See Remarks & $\begin{array}{l}\text { Wl: } \\
\text { S } \\
\text { A: }\end{array}$ & $\begin{array}{l}\text { WI: } \\
\text { F: } \\
\text { A: } \\
\text { F: }\end{array}$ & $\begin{array}{l}\text { Normally; a leak of air into a can } \\
\text { will result in formation of PuO2; } \\
\text { however, if the leak is very, very } \\
\text { small, reactive materials could still } \\
\text { be present. Reactivity of materials } \\
\text { is bounded by Pu hydride case, } \\
\text { above. }\end{array}$ \\
\hline $\mathrm{OM}-4 \mathrm{a}$ & 4 & $\begin{array}{l}\text { W'bat if typically-seen very fine dust } \\
\text { coming from opened can is } \mathrm{Pu} \\
\text { hydride? }\end{array}$ & $\begin{array}{l}\text { Powder will rapidjy react in air - } \\
\text { "Sparky". } \\
\text { A: See OM-3b. }\end{array}$ & See OM-3b. & See OM-3b. & See OM-3b. & $\begin{array}{l}\text { W't: } \\
\text { SO } \\
\text { A: } \\
\text { 1) S0 } \\
\text { 2) So } \\
\text { 3) So }\end{array}$ & $\begin{array}{l}\text { WI: } \\
\text { F3 } \\
\text { A: } \\
\text { 1)F3 } \\
\text { 2) F3 } \\
\text { 3)F3 }\end{array}$ & Essentially the same as OM-3b. \\
\hline
\end{tabular}




\begin{tabular}{|c|c|c|c|c|c|c|c|c|c|}
\hline \multicolumn{10}{|c|}{ Deviation Guides: (1) No, None (2) Less, Lower (3) More, Higher (4) Part of (5) As Well As (6) Reverse (7) Other Than, Sooner, Later, Where Else } \\
\hline $\begin{array}{l}\text { Node } \\
\text { ID }\end{array}$ & Step \# & "What If" question & Consequence & Cause(s) of "What If" & $\begin{array}{l}\text { Engineered Safety } \\
\text { Feature(s) for "What If" } \\
\text { and Accident }\end{array}$ & $\begin{array}{l}\text { Administrative } \\
\text { Safety Feature(s) } \\
\text { for "What If" and } \\
\text { Accident }\end{array}$ & $\begin{array}{l}\text { Cons } \\
\text { Cat }\end{array}$ & $\begin{array}{l}\text { Freq } \\
\text { Cat }\end{array}$ & Remarks \\
\hline OM-4b & 4 & $\begin{array}{l}\text { What if typically-seen very fine dust } \\
\text { coming from opened can is non- } \\
\text { reactive Pu compounds? (c.g., oxide) }\end{array}$ & $\begin{array}{l}\text { Increased holdup in glovebox; } \\
\text { higher dose rate. }\end{array}$ & Sce Remarks & See Remarks & See Remarks & so & F3 & Judged to be inconsequential. \\
\hline $\mathrm{OM}-4 \mathrm{c}$ & 4 & $\begin{array}{l}\text { What if the inmost can is turned } \\
\text { upside-down, agitated, dropped, } \\
\text { tumed sideway's, etc., before being } \\
\text { opened? }\end{array}$ & $\begin{array}{l}\text { Suspension of more particulate, } \\
\text { which may escape and react.. } \\
\text { "Sparky". } \\
\text { A: See OM- } 3 \text { b. }\end{array}$ & See OM-3b. & Sec OM-3b. & Sec OM-3b. & $\begin{array}{l}\text { WI: } \\
\text { SO } \\
\text { A: } \\
\text { 1) S0 } \\
\text { 2) SO } \\
\text { 3) SO }\end{array}$ & $\begin{array}{l}\text { WI: } \\
\text { F3 } \\
\text { A: } \\
\text { 1) F3 } \\
\text { 2) F3 } \\
\text { 3)F3 }\end{array}$ & $\begin{array}{l}\text { Calculations show } \sim 0.75 \mathrm{~g} \text { could } \\
\text { be released from a pressurized can; } \\
\text { this amount will likely be less than } \\
\text { that. }\end{array}$ \\
\hline OM-5 & 5 & & & & & & & & Inconsequential \\
\hline ON1-6at & 6 & $\begin{array}{l}\text { What if the conlents are not inspected } \\
\text { before being dumped. and the } \\
\text { material is burning? }\end{array}$ & $\begin{array}{l}\text { Iarger surface area available for } \\
\text { reaction, greater exposure to } \\
\text { oxygen. } \\
\text { A: Fire in glovebox, assuming } \\
\text { contact with sufficient } \\
\text { combustibles. }\end{array}$ & Sec OM-1a. & See OM-1a. & Sec OMI.1a. & $\begin{array}{l}\text { W'I: } \\
\text { SO } \\
\text { A: } \\
\text { S1 }\end{array}$ & $\begin{array}{l}\text { W'I: } \\
\text { F3 } \\
\text { A: } \\
\text { F2 }\end{array}$ & $\begin{array}{l}\text { Single container will not contain } \\
\text { more than } 200 \mathrm{~g} \text { of Pu hydride, and } \\
\text { this quantity of hydride reacting } \\
\text { anywhere in the glovebox is not } \\
\text { enough to pressurize glovebox. } \\
\text { This can be proven scientifically } \\
\text { within a can, and by } ~-50 \text { years of } \\
\text { processing experience for outside } \\
\text { the can, in the glovebox. (See } \\
\text { Thurman for details). } \\
\text { This is the highest likelihood for a } \\
\text { fire in the glovebox - lots of } \\
\text { glowing, burning, sparking } \\
\text { material spread around. }\end{array}$ \\
\hline $\mathrm{OM}-6 \mathrm{~b}$ & 6 & $\begin{array}{l}\text { W'hat if forcign (e.g., alumimum foil) } \\
\text { material is in the can? }\end{array}$ & $\begin{array}{l}\text { W': none } \\
\text { A: foreign material trapping } \\
\text { corrosion products and igniting } \\
\text { while it is mixed with combustibles } \\
\text { and causing a glovebox fire }\end{array}$ & $\begin{array}{l}\text { Wi: foreign material } \\
\text { originally packaged with Pu } \\
\text { metal }\end{array}$ & $\begin{array}{l}\text { WI: none } \\
\text { A: See OM-la. }\end{array}$ & $\begin{array}{l}\text { WI: none } \\
\text { A: See OM-la. }\end{array}$ & $\begin{array}{l}\text { See OM. } \\
\text { la. }\end{array}$ & $\begin{array}{l}\text { See } \\
\text { OM- } \\
\text { la. }\end{array}$ & $\begin{array}{l}\text { It is not amicipated that foreign } \\
\text { materials will be present. }\end{array}$ \\
\hline OM-7 & 7 & & & & & & & & Nothing to evaluate. \\
\hline
\end{tabular}




\begin{tabular}{|c|c|c|c|c|c|c|c|c|c|}
\hline $\begin{array}{l}\text { Node } \\
\text { ID }\end{array}$ & Step \# & "What If" question & Consequence & Cause(s) of "What If" & $\begin{array}{l}\text { Engineered Safety } \\
\text { Feature(s) for "What If" } \\
\text { and Accident }\end{array}$ & $\begin{array}{l}\text { Administrative } \\
\text { Safety Feature(s) } \\
\text { for "What If" and } \\
\text { Accident }\end{array}$ & $\begin{array}{l}\text { Cons } \\
\text { Cat }\end{array}$ & $\begin{array}{l}\text { Freq } \\
\text { Cat }\end{array}$ & Remarks \\
\hline OM-8a & 8 & $\begin{array}{l}\text { What if we do not place a stip-lid on } \\
\text { top of a can full of burning material? }\end{array}$ & $\begin{array}{l}\text { Continues to burn; source of } \\
\text { ignition for combustibles. } \\
\text { A: Fire in glovebox. assuming } \\
\text { contact with sufficient } \\
\text { combustibles. }\end{array}$ & See OM-la. & See OM-la. & See OM-1a. & $\begin{array}{l}\text { WI: } \\
\text { So } \\
\text { A: } \\
\text { S1 }\end{array}$ & $\begin{array}{l}\text { WI: } \\
\text { F3 } \\
\text { A: } \\
\text { F2 }\end{array}$ & $\begin{array}{l}\text { We don't expect to see fast- } \\
\text { burning, high-temperature buttons, } \\
\text { as we don't have enough hydride } \\
\text { to do that. } \\
\text { Calculations exist to verify that. }\end{array}$ \\
\hline OM1-8b & 8 & $\begin{array}{l}\text { What if an Nlarm sounds and the } \\
\text { room is cvacuated with burning } \\
\text { material still sitting exposed in the } \\
\text { glorebox? }\end{array}$ & $\begin{array}{l}\text { Continues to burm: source of } \\
\text { ignition for combustibles. } \\
\text { A: Fire in glovebox. assuming } \\
\text { contact with sufficiem } \\
\text { combustibles. }\end{array}$ & Sec OM-1a. & See OM-1a. & See OM-1a. & $\begin{array}{l}\text { WI: } \\
\text { SO } \\
\text { A: } \\
\text { SI }\end{array}$ & $\begin{array}{l}\text { WI: } \\
\text { F3 } \\
\text { A: } \\
\text { F2 }\end{array}$ & \\
\hline ONI-9a & 9 & $\begin{array}{l}\text { What if normal-appearing product } \\
\text { begins to burn when in"s poured into } \\
\text { tray? }\end{array}$ & Same as 8. & See OM-la. & Sec OM-1a. & See OMfla. & $\begin{array}{l}\text { WI: } \\
\text { so } \\
\text { A: } \\
\text { si }\end{array}$ & $\begin{array}{l}\text { WI: } \\
\text { F3 } \\
\text { A: } \\
\text { F2 }\end{array}$ & $\begin{array}{l}\text { Three things that could be done: } \\
\text { 1) Let it bum. } \\
\text { 2) Cover burning material with } \\
\text { slip-lid can. } \\
\text { 3) Cover it will } \mathrm{M} / g \mathrm{O} \text { sand. }\end{array}$ \\
\hline $\mathrm{OM}-9 \mathrm{~b}$ & 9 & $\begin{array}{l}\text { What if the material was poured on } \\
\text { the floor of the glovebox rather than } \\
\text { in the tray? }\end{array}$ & Same as 8. & Sec OM.1a. & See OM-la. & Sec OM-1a. & $\begin{array}{l}\text { WI: } \\
\text { so } \\
\text { A: } \\
\text { S1 }\end{array}$ & $\begin{array}{l}\text { W'I: } \\
\text { F3 } \\
\text { A: } \\
\text { F2 }\end{array}$ & $\begin{array}{l}\text { This would likely pose a lower } \\
\text { hazard because of a higher heat } \\
\text { transfer through the floor of the } \\
\text { glovebox. }\end{array}$ \\
\hline
\end{tabular}




\begin{tabular}{|c|c|c|c|c|c|c|c|c|c|}
\hline \multicolumn{10}{|c|}{ Deviation Guides: (1) No, None (2) Less, Lower (3) More, Higher (4) Part of (5) As Well As (6) Reverse (7) Other Than, Sooner, Later, Where Else } \\
\hline $\begin{array}{l}\text { Node } \\
\text { ID }\end{array}$ & Step \# & "What If" question & Consequence & Cause(s) of "What If" & $\begin{array}{l}\text { Engineered Safety } \\
\text { Feature(s) for "What If" } \\
\text { and Accident }\end{array}$ & $\begin{array}{l}\text { Administrative } \\
\text { Safety Feature(s) } \\
\text { for "What If" and } \\
\text { Accident }\end{array}$ & $\begin{array}{l}\text { Cons } \\
\text { Cat }\end{array}$ & $\begin{array}{l}\text { Freq } \\
\text { Cat }\end{array}$ & Remarks \\
\hline OM-9c & 9 & $\begin{array}{l}\text { What if the material does not come } \\
\text { out of the can? }\end{array}$ & $\begin{array}{l}\text { W'I: can't process material and } \\
\text { requires further evaluation to get it } \\
\text { out. } \\
\text { AI: puncher of glove with tool } \\
\text { during forced extraction } \\
\text { A2: reactive piece ejected and } \\
\text { lands on combustible material } \\
\text { causing a glovebox fire. }\end{array}$ & $\begin{array}{l}\text { Panneled can or hardened } \\
\text { corrosion products }\end{array}$ & $\begin{array}{l}\text { WI: none } \\
\text { A1: none } \\
\text { A2: See OM-1a. }\end{array}$ & $\begin{array}{l}\text { WI: none } \\
\text { A1: training, treatment of } \\
\text { contaminated wound } \\
\text { A2: See ON-1 }\end{array}$ & $\begin{array}{l}\text { WI: } \\
\text { So } \\
\text { A1: } \\
\text { Si } \\
\text { A2: See } \\
\text { OM1-1a. }\end{array}$ & $\begin{array}{l}\mathrm{Al}: \\
\mathrm{F} 3 \\
\mathrm{~A} 2 \\
\mathrm{~A} 2 \\
\mathrm{See} \\
\mathrm{OM}- \\
\mathrm{la}-\end{array}$ & \\
\hline ON-10a & 10a & $\begin{array}{l}\text { W'hat if a stable-looking button } \\
\text { cnumbles when you pick it up for } \\
\text { brusthing? }\end{array}$ & $\begin{array}{l}\text { Possibility of generating dust: } \\
\text { increased holdup in glovebox; } \\
\text { higher dose rate. }\end{array}$ & See Remark & See Remark & See Remark & so & $\mathrm{F} 3$ & $\begin{array}{l}\text { Amount of generated dust judged } \\
\text { not to have a significant impact. }\end{array}$ \\
\hline ONI-10b & 10a & $\begin{array}{l}\text { W'hat if brushing is over-vigorous, } \\
\text { leading to large amounts of suspended } \\
\text { powder? }\end{array}$ & $\begin{array}{l}\text { Malerial suspended in glovebox } \\
\text { atmosplere. }\end{array}$ & See Remark & See Remark & See Remark & so & 10 & $\begin{array}{l}\text { Years of button brushing have } \\
\text { shown that this is not a concern. }\end{array}$ \\
\hline $0.1 \cdot 11$ & 11 & & & & & & & & Activity covered by $A B$. \\
\hline OMr $12 a$ & 12 & $\begin{array}{l}\text { W'lat if the accumulation of reactive } \\
\text { brushed material in the glorebox } \\
\text { exceeds our cesperience base? (200g } \\
\text { of brushed material from multiple } \\
\text { containers). }\end{array}$ & $\begin{array}{l}\text { Potential for pressurization of } \\
\text { glovebox } \\
\text { A: Loss of glovebox containment } \\
\text { and contamination spread to room. }\end{array}$ & Lack of inventory control. & $\begin{array}{l}\text { WI: none. } \\
\text { A: CANis and glovebox differential } \\
\text { pressure and HEPA fillered exhaust }\end{array}$ & $\begin{array}{l}\text { WI: Accountability: } \\
\text { Inventory control system } \\
\text { for brushed material. } \\
\text { A: none. }\end{array}$ & $\begin{array}{l}\text { WI: } \\
\text { so } \\
\text { A: } \\
\text { Si }\end{array}$ & $\begin{array}{l}\text { WI: } \\
\text { F2 } \\
\text { A: } \\
\text { F2 }\end{array}$ & $\begin{array}{l}\text { Propose: hotplate in } 636 \text { to heat } \\
\text { brushed material to } 350^{\circ} \mathrm{C} \text { to } \\
\text { passivate the material OR send } \\
\text { brushed material over to } 21 \mathrm{~A} \text { in } \\
\text { single-batch amounts or single- } \\
\text { brushing amounts. }\end{array}$ \\
\hline
\end{tabular}


Deviation Guides: (1) No, None (2) Less, Lower (3) More, Higher (4) Part of (5) As Well As (6) Reverse (7) Other Than, Sooner, Later, Where Else

\begin{tabular}{|c|c|c|c|c|c|c|c|c|c|}
\hline $\begin{array}{l}\text { Node } \\
\text { ID }\end{array}$ & Step \# & "What If" question & Consequence & Cause(s) of "What If" & $\begin{array}{l}\text { Engineered Safety } \\
\text { Feature(s) for "What If" } \\
\text { and Accident }\end{array}$ & $\begin{array}{l}\text { Administrative } \\
\text { Safety Feature(s) } \\
\text { for "What If" and } \\
\text { Accident }\end{array}$ & $\begin{array}{l}\text { Cons } \\
\text { Cat }\end{array}$ & $\begin{array}{l}\text { Freq } \\
\text { Cat }\end{array}$ & Remarks \\
\hline OMI-12b & 12 & $\begin{array}{l}\text { What if the brushed reactive material } \\
\text { appears to burn when poured into a } \\
\text { new can? }\end{array}$ & $\begin{array}{l}\text { Source of ignition for } \\
\text { combustiblcs. } \\
\text { A: Fire in glovebox, assuming } \\
\text { contact with sufficient } \\
\text { combustibles }\end{array}$ & $\begin{array}{l}\text { Intentional action. } \\
\text { A: Sec OM-1a }\end{array}$ & See OM-la & See OM-1a & $\begin{array}{l}\text { WI: } \\
\text { so } \\
\text { A: } \\
\text { SI }\end{array}$ & $\begin{array}{l}\text { WI: } \\
\text { F3 } \\
\text { A: } \\
\text { F2 }\end{array}$ & $\begin{array}{l}\text { Reactive materials close to } \\
\text { combustibles. } \\
\text { You would expect to see reactions } \\
\text { when pouring this } 200 \mathrm{~g} \text { of highly- } \\
\text { reactive, non-passivated brushed } \\
\text { material through the air to a new } \\
\text { can, or sweeping it from the tray to } \\
\text { a can. }\end{array}$ \\
\hline
\end{tabular}

PFP Opening Mctal Itcms and Thermal Stabilization in GB HC-21A "What If" Hazards Evaluation Work Shcets

Hazards Evaluation Tcam: R.B. Gelman, E.P. Bonadic, E.L. Kaucr, C.A. Carro, D. A. Clapp, Leader, A.B. Rau, Scribe

Datc Hazards Evaluation Conducted: 15 Junc 1999

\begin{tabular}{|c|c|c|c|c|c|c|c|c|c|}
\hline TS-1 & 1 & & & & & & & & $\begin{array}{l}\text { Hazards associated with these } \\
\text { activities are addressed in the } \\
\text { Thermal Stabilization Addendum } \\
\text { to W'HC-SD-CP-SAR-021. }\end{array}$ \\
\hline TS-2 & 2 & & & & & & & & $\begin{array}{l}\text { Covered in OM-3 }(a, b \text {, and } c) \text { see } \\
\text { above. }\end{array}$ \\
\hline TS-3 & 3 & & & & & & & & $\begin{array}{l}\text { Covered in OM-4 }(a, b \text {, and c) see } \\
\text { abovis }\end{array}$ \\
\hline TS-4a & 4 & What if hydride is present and reacts & $\begin{array}{l}\text { WI: material comtinues to react to } \\
\text { completion; source of ignition for } \\
\text { combustibles } \\
\text { A: fire in glovebox assuming } \\
\text { contact with sufficient } \\
\text { combustibles. }\end{array}$ & Sce OM-la. & Sce OM-1a. & See OM-1a. & $\begin{array}{l}\text { See OM- } \\
\text { la. }\end{array}$ & $\begin{array}{l}\text { See } \\
\text { OMl- } \\
\text { la. }\end{array}$ & See OM-la. \\
\hline
\end{tabular}




\begin{tabular}{|c|c|c|c|c|c|c|c|c|c|}
\hline \multicolumn{10}{|c|}{ Deviation Guides: (1) No, None (2) Less, Lower (3) More, Higher (4) Part of (5) As Well As (6) Reverse (7) Other Than, Sooner, Later, Where Else } \\
\hline $\begin{array}{l}\text { Node } \\
\text { ID }\end{array}$ & Stcp \# & "What If" question & Consequence & Cause(s) of "What If" & $\begin{array}{l}\text { Engineered Safety } \\
\text { Feature(s) for "What If" } \\
\text { and Accident }\end{array}$ & $\begin{array}{l}\text { Administrative } \\
\text { Safety Feature(s) } \\
\text { for "What If" and } \\
\text { Accident }\end{array}$ & $\begin{array}{l}\text { Cons } \\
\text { Cat }\end{array}$ & $\begin{array}{l}\text { Freq } \\
\text { Cat }\end{array}$ & Remarks \\
\hline rs.4b & 4 & $\begin{array}{l}\text { What if metal is present and begins to } \\
\text { bum? }\end{array}$ & $\begin{array}{l}\text { W': material continues to react to } \\
\text { completion; source of ignition for } \\
\text { combustibles } \\
\text { A: fire in glovebos assuming } \\
\text { contact with sufficient } \\
\text { combustibles. }\end{array}$ & See OM-1a. & See OM-la. & Sec OM-la. & $\begin{array}{l}\text { See OM- } \\
\text { la. }\end{array}$ & $\begin{array}{l}\text { See } \\
\text { OM- } \\
\text { la. }\end{array}$ & See OMrla. \\
\hline TS-4c & 4 & $\begin{array}{l}\text { What if we spill it on the glorebox } \\
\text { floor? }\end{array}$ & See OM-9b. & See OM-9b. & See OM-9b. & Sec OM-9b. & $\begin{array}{l}\text { Sec OM- } \\
9 \mathrm{~b} \text {. }\end{array}$ & $\begin{array}{l}\text { Sec } \\
\text { OM. } \\
9 \mathrm{~b} .\end{array}$ & See OMI-9b. \\
\hline TS-5 & 5 & & & & & & & & No safety impacts. \\
\hline ts.6a & 6 & $\begin{array}{l}\text { What if corrosion products react or } \\
\text { metal ignites on conveyor? }\end{array}$ & $\begin{array}{l}\text { W'I: provides a heal ignition } \\
\text { source } \\
\text { A: loss of glovebox containment } \\
\text { and contamination spread to room }\end{array}$ & none & $\begin{array}{l}\text { W': none } \\
\text { A: See OM-12a. }\end{array}$ & $\begin{array}{l}\text { W'l: none } \\
\text { A: procedures and training }\end{array}$ & $\begin{array}{l}\text { Wi:S0 } \\
\mathrm{A}: \mathrm{S1}\end{array}$ & $\begin{array}{l}\text { WI: F2 } \\
\text { A: F2 }\end{array}$ & $\begin{array}{l}\text { There is a very short residence } \\
\text { time (e.g., liss than a minute) on } \\
\text { the conveyor. }\end{array}$ \\
\hline$T S \cdot 6 \mathrm{~b}$ & 6 & $\begin{array}{l}\text { What if furnace boat contents spill on } \\
\text { conveyor? }\end{array}$ & $\begin{array}{l}\text { W'I: possibility of creating dust } \\
\text { and increalsed holdup in glovebox } \\
\text { A: higher dose rates to operators }\end{array}$ & $\begin{array}{l}\text { Furnace boat becomes } \\
\text { entangled with glovebox glove } \\
\text { or operator drops fumace boat. }\end{array}$ & Furnace boal cover & $\begin{array}{l}\text { Procedures and traing } \\
\text { and glovebox gloves are } \\
\text { withdrawn and bungeed }\end{array}$ & so & $\mathrm{F} 3$ & \\
\hline TS-6c & 6 & $\begin{array}{l}\text { What if boat cover left off and boat } \\
\text { inadvertently transferred to HC-18BS } \\
\text { and reactive corrosion prodects } \\
\text { disperse and ignite? }\end{array}$ & $\begin{array}{l}\text { WI: exposed powder } \\
\text { A: potential pressurization of } \\
\text { glovebox if more than } 200 \text { grams } \\
\text { of hydride }\end{array}$ & WI: human errors & $\begin{array}{l}\text { Glovebox differential pressure, } \\
\text { CANs and IIEPA fiter exhatust }\end{array}$ & $\begin{array}{l}\text { Procedures and training. } \\
200 \text { gram hydride } \\
\text { restriction }\end{array}$ & S1 & $\mathrm{Fl}$ & $\begin{array}{l}\text { Frequency judged to be at lower } \\
\text { end of range (i.e., approaching } 10 \\
\text { o.per year. }\end{array}$ \\
\hline TS-7a & 7 & $\begin{array}{l}\text { What if material not heated } 10>300 \\
{ }^{\circ} \mathrm{C} \text { ? }\end{array}$ & $\begin{array}{l}\text { Residual hydride and potential } \\
\text { exothermic reactions during } \\
\text { subsequent processes }\end{array}$ & $\begin{array}{l}\text { Equipment failure and failure } \\
\text { to detect }\end{array}$ & $\begin{array}{l}\text { Controller programmed to raise } \\
\text { temperature to } 1000^{\circ} \mathrm{C} \\
\text { Setpoint temperature deviation } \\
\text { alarms }\end{array}$ & $\begin{array}{l}\text { Logbook entry and check } \\
\text { chart recorders per } \\
\text { procedure }\end{array}$ & s1 & $\mathrm{F} 1$ & $\begin{array}{l}\text { This event could result in a } \\
\text { glovebox fire. Glovebox fires have } \\
\text { been previously identified in this } \\
\text { Hazards Analysis with a } \\
\text { probability of }>\mathrm{F} 1 \text {. }\end{array}$ \\
\hline
\end{tabular}


Deviation Guides: (1) No, None (2) Less, Lower (3) More, Higher (4) Part of (5) As Well As (6) Reverse (7) Other Than, Sooner, Later, Where Else

\begin{tabular}{|c|c|c|c|c|c|c|c|c|c|}
\hline $\begin{array}{l}\text { Node } \\
\text { ID }\end{array}$ & Step \# & "What If" question & Consequence & Cause(s) of "What If" & $\begin{array}{l}\text { Engineered Safety } \\
\text { Feature(s) for "What If" } \\
\text { and Accident }\end{array}$ & $\begin{array}{l}\text { Administrative } \\
\text { Safety Feature(s) } \\
\text { for "What If" and } \\
\text { Accident }\end{array}$ & $\begin{array}{l}\text { Cons } \\
\text { Cat }\end{array}$ & $\begin{array}{l}\text { Freq } \\
\text { Cat }\end{array}$ & Remarks \\
\hline TS. $7 \mathrm{~b}$ & 7 & $\begin{array}{l}\text { What if there is no vacuum and } \\
\text { hydrides are present? }\end{array}$ & $\begin{array}{l}\text { Potentially flammable } \\
\text { concentration of hydrogen within } \\
\text { furnace and potential deflagration }\end{array}$ & $\begin{array}{l}\text { Human error or equipment } \\
\text { failure }\end{array}$ & $\begin{array}{l}\text { Glovebox differential pressure, } \\
\text { CAMs, HEPA filter exhaust }\end{array}$ & Procedures and training & $\begin{array}{l}\text { W'I:SO } \\
\text { A: SI }\end{array}$ & $\begin{array}{l}\text { WI: } \\
\text { F3 } \\
\text { A: F2 }\end{array}$ & \\
\hline
\end{tabular}




\subsection{HAZARD EVALUATION RESULTS}

Table 3 summarizes all of the potential accidents with significance worker consequences.

Table 3. Accidents With Potential Significant Worker Consequences (S1). (2 sheets)

\begin{tabular}{|c|c|c|c|c|}
\hline ID\# & Accident & Cause & $\begin{array}{l}\text { Cons. } \\
\text { Cat. }\end{array}$ & $\begin{array}{l}\text { Freq. } \\
\text { Cat. }\end{array}$ \\
\hline OM-1a & Fire in glovebox 636 or $\mathrm{HC}-21 \mathrm{~A}$ & $\begin{array}{l}\text { Superfluous and uncontrolled combustibles ignited by corrosion product } \\
\text { reaction sparks from opened can. }\end{array}$ & S1 & F2 \\
\hline OM-1b & Fire in glovebox 636 or $\mathrm{HC}-21 \mathrm{~A}$ & $\begin{array}{l}\text { Superfluous and uncontrolled combustibles ignited by corrosion product } \\
\text { reaction sparks from opened can. }\end{array}$ & S1 & F2 \\
\hline OM-1c & Fire in glovebox 636 or HC-21A & $\begin{array}{l}\text { Superfluous and uncontrolled combustibles ignited by corrosion product } \\
\text { reaction sparks from opened can. }\end{array}$ & S1 & F1 \\
\hline OM-1d & Fire in glovebox 636 or $\mathrm{HC}-21 \mathrm{~A}$ & $\begin{array}{l}\text { Superfluous and uncontrolled combustibles ignited by corrosion product } \\
\text { reaction sparks from opened can. }\end{array}$ & S1 & $\mathrm{F} 2$ \\
\hline OM-2 & Fire in glovebox 636 or $\mathrm{HC}-21 \mathrm{~A}$ & $\begin{array}{l}\text { Superfluous and uncontrolled combustibles ignited by corrosion product } \\
\text { reaction sparks from opened can. }\end{array}$ & S1 & $\overline{\mathrm{F} 3}$ \\
\hline$\overline{\mathrm{OM}-3 \mathrm{a}}$ & Fire in glovebox 636 or $\mathrm{HC}-21 \mathrm{~A}$ & $\begin{array}{l}\text { Superfluous and uncontrolled combustibles ignited by corrosion product } \\
\text { reaction sparks from opened can. }\end{array}$ & SI & F2 \\
\hline $\mathrm{OM}-3 \mathrm{~b}(1)$ & Fire in glovebox 636 or $\mathrm{HC}-21 \mathrm{~A}$ & $\begin{array}{l}\text { Superfluous and uncontrolled combustibles ignited by corrosion product } \\
\text { reaction sparks from opened can. }\end{array}$ & S1 & $\overline{F 3}$ \\
\hline OM-3c & Fire in glovebox 636 or $\mathrm{HC}-21 \mathrm{~A}$ & $\begin{array}{l}\text { Superfluous and uncontrolled combustibles ignited by corrosion product } \\
\text { reaction sparks from opened can. }\end{array}$ & S1 & F2 \\
\hline OM-6a & Fire in glovebox 636 or $\mathrm{HC}-21 \mathrm{~A}$ & $\begin{array}{l}\text { Superfluous and uncontrolled combustibles ignited by corrosion product } \\
\text { reaction sparks from opened can. }\end{array}$ & S1 & F2 \\
\hline OM-6b & Fire in glovebox 636 or HC-21A & $\begin{array}{l}\text { Superfluous and uncontrolled combustibles ignited by corrosion product } \\
\text { reaction sparks from opened can. }\end{array}$ & S1 & $\overline{\mathrm{F} 2}$ \\
\hline$\overline{\mathrm{OM}}-8 \mathrm{a}$ & Fire in glovebox 636 or $\mathrm{HC}-21 \mathrm{~A}$ & $\begin{array}{l}\text { Superfluous and uncontrolled combustibles ignited by corrosion product } \\
\text { reaction sparks from opened can. }\end{array}$ & SI & F2 \\
\hline$\overline{\mathrm{OM}}-8 \mathrm{~b}$ & Fire in glovebox 636 or $\mathrm{HC}-21 \AA$ & $\begin{array}{l}\text { Superfluous and uncontrolled combustibles ignited by corrosion product } \\
\text { reaction sparks from opened can. }\end{array}$ & S1 & F2 \\
\hline OM-9a & Fire in glovebox 636 or $\mathrm{HC}-21 \mathrm{~A}$ & $\begin{array}{l}\text { Superfluous and uncontrolled combustibles ignited by corrosion product } \\
\text { reaction sparks from opened can. }\end{array}$ & S1 & F2 \\
\hline$\overline{\mathrm{OM}}-9 \mathrm{~b}$ & Fire in glovebox 636 or $\mathrm{HC}-21 \mathrm{~A}$ & $\begin{array}{l}\text { Superfluous and uncontrolled combustibles ignited by corrosion product } \\
\text { reaction sparks from opened can. }\end{array}$ & $\overline{\mathrm{Si}}$ & F2 \\
\hline $\mathrm{OM}-9 \mathrm{c}(1)$ & Hand puncture wound with Pu injection & Difficult extraction of solids from "paneled" - inadequate extraction tools. & S1 & F3 \\
\hline OM-9c(2) & Fire in glovebox 636 or $\mathrm{HC}-21 \mathrm{~A}$ & $\begin{array}{l}\text { Superfluous and uncontrolled combustibles ignited by corrosion product } \\
\text { reaction sparks from opened can. }\end{array}$ & S1 & F2 \\
\hline
\end{tabular}


Table 3. Accidents With Potential Significant Worker Consequences (S1). (2 sheets)

\begin{tabular}{|l|l|l|l|l|}
\hline ID\# & Accident & Cause & $\begin{array}{l}\text { Cons. } \\
\text { Cat. }\end{array}$ & $\begin{array}{l}\text { Freq. } \\
\text { Cat. }\end{array}$ \\
\hline OM-12a & Loss of 636 or HC-21A glovebox containment & $\begin{array}{l}\text { Accumulation and subsequent reaction of more than 200g of the most } \\
\text { reactive corrosion products - reaction produces enough energy to } \\
\text { pressurize glovebox to the point of breach of containment. }\end{array}$ & S1 \\
\hline OM-12b & Fire in glovebox 636 or HC-21A & $\begin{array}{l}\text { Superfluous and uncontrolled combustibles ignited by corrosion product } \\
\text { reaction sparks from opened can. }\end{array}$ & S1 & F2 \\
\hline TS-2 & Fire in glovebox HC-21A & $\begin{array}{l}\text { Superfluous and uncontrolled combustibles ignited by corrosion product } \\
\text { reaction sparks from opened can. }\end{array}$ & S1 \\
\hline TS-4a & Fire in glovebox HC-21A & $\begin{array}{l}\text { Superfluous and uncontrolled combustibles ignited by corrosion product } \\
\text { reaction sparks from opened can. }\end{array}$ & S1 \\
\hline TS-4b & Fire in glovebox HC-21A & $\begin{array}{l}\text { Superfluous and uncontrolled combustibles ignited by corrosion product } \\
\text { reaction sparks from opened can. }\end{array}$ & S1 \\
\hline TS-4c & Fire in glovebox HC-21A & $\begin{array}{l}\text { Superfluous and uncontrolled combustibles ignited by corrosion product } \\
\text { reaction sparks from opened can. }\end{array}$ & S1 \\
\hline TS-6a & Loss of HC-21A glovebox containment & $\begin{array}{l}\text { Spontaneous reaction of corrosion products while traveling conveyor - } \\
\text { ignites and/or melts glove that may be left in box causing leak path from } \\
\text { glovebox. }\end{array}$ & S1 \\
\hline TS-6c & Loss of HC-21A glovebox containment & $\begin{array}{l}\text { More than 200 grams of hydride being conveyed - reaction produces } \\
\text { enough energy to pressurize glovebox to the point of breach of } \\
\text { containment. }\end{array}$ & S1 \\
\hline TS-7a & Fire in glovebox HC-21A & $\begin{array}{l}\text { Material not heated to stabilization temperature leaving residual reactive } \\
\text { material which may react while not controlled in subsequent } \\
\text { processing/handling activities. } \\
\text { Superfluous and uncontrolled combustibles ignited by corrosion product } \\
\text { reaction sparks from opened can. }\end{array}$ & S1 \\
& & $\begin{array}{l}\text { Simultaneous loss of furnace vacuum and presence of hydrides causing } \\
\text { flammable concentrations of hydrogen with ignition. }\end{array}$ & F2 \\
\hline TS-7b & $\begin{array}{l}\text { (1)Fire in glovebox HC-21A } \\
\text { (2)Loss of glovebox containment (HC-???) }\end{array}$ & F1 & F1 \\
\hline
\end{tabular}




\section{DISTRIBUTION SHEET}

To

Distribution

Project Title/Work Order

Hazards Evaluation of Plutonium Metal opening and Stabilization
From

A. I. Ramble

Page 1 of 1

Date $7 / 19 / 99$

EDT No. 619986

ECN No. N/A Name

\begin{tabular}{|c|c|c|c|c|c|}
\hline & MSIN & $\begin{array}{c}\text { Text } \\
\text { With All } \\
\text { Attach. }\end{array}$ & Text Only & $\begin{array}{l}\text { Attach.I } \\
\text { Appendix } \\
\text { Only }\end{array}$ & $\begin{array}{l}\text { EDT/ECN } \\
\text { Only }\end{array}$ \\
\hline & $T 5-55$ & $\mathrm{x}$ & & & \\
\hline & $T 5-08$ & $x$ & & & \\
\hline & T5-11 & $x$ & & & \\
\hline & T5-54 & $\mathrm{x}$ & & & \\
\hline $7-1929$ & T5-55 & $\mathrm{x}$ & & & \\
\hline & T5-57 & $x$ & & & \\
\hline & T5-50 & $x$ & & & \\
\hline & $T 4-15$ & $\mathrm{x}$ & & & \\
\hline & B1-07 & $x$ & & & \\
\hline & A $3-02$ & $x$ & & & \\
\hline & $42-53$ & $x$ & & & \\
\hline & & & & - & \\
\hline & & & & & \\
\hline & & & & & \\
\hline & & & & & \\
\hline & & & & & \\
\hline & & & & & \\
\hline & & & & & \\
\hline & & & & & \\
\hline & & & & & \\
\hline & & & & & \\
\hline & & & & & \\
\hline & & & & & \\
\hline & & & & & \\
\hline & & & & & \\
\hline & & & & & \\
\hline & & & & & \\
\hline & & & & & \\
\hline & & & & & \\
\hline & & & & & \\
\hline
\end{tabular}

\begin{tabular}{|c|c|c|c|c|c|}
\hline & MSIN & $\begin{array}{c}\text { Text } \\
\text { With All } \\
\text { Attach. }\end{array}$ & Text Only & $\begin{array}{l}\text { Attach.I } \\
\text { Appendix } \\
\text { Only }\end{array}$ & $\begin{array}{l}\text { EDT/ECN } \\
\text { Only }\end{array}$ \\
\hline & $T 5-55$ & $\mathrm{x}$ & & & \\
\hline & T5-08 & $x$ & & & \\
\hline & $T 5-11$ & $x$ & & & \\
\hline & T5-54 & $x$ & & & \\
\hline $7-1929$ & $T 5-55$ & $\mathrm{x}$ & & & \\
\hline & T5-57 & $\mathrm{x}$ & & & \\
\hline & $T 5-50$ & $x$ & & & \\
\hline & $T 4-15$ & $\mathrm{x}$ & & & \\
\hline & B1-07 & $x$ & & & \\
\hline & A $3-02$ & $x$ & & & \\
\hline & $42-53$ & $x$ & & & \\
\hline & & & & & \\
\hline & & & & & \\
\hline & & & & & \\
\hline & & & & & \\
\hline & & & & & \\
\hline & & & & & \\
\hline & & & & & \\
\hline & & & & & \\
\hline & & & & & \\
\hline & & & & & \\
\hline & & & & & \\
\hline & & & & & \\
\hline & & & & & \\
\hline & & & & & \\
\hline & & & & & \\
\hline & & & & & \\
\hline & & & & & \\
\hline & & & & & \\
\hline & & & & & \\
\hline
\end{tabular}

E. P. Bonadie

R. E. Gregory

3:-E.Mum D.A. Connzes ST

A. L. Ramble

H. R. Risenmay

P. E. Roege

D. R. Speer

S. zeller

Central Files (Orig. + 2 copies)

Docket Files (2 copies)

DorlRl Reading Room 